\title{
THE MEASUREMENT OF PULMONARY DIFFUSING CAPACITY FOR CARBON MONOXIDE BY A REBREATHING METHOD*†
}

\author{
BY BENJAMIN M. LEWIS, TAI-HON LIN, FRANCES E. NOE \\ AND ERNEST J. HAYFORD-WELSING \& \\ WITH THE TECHNICAL ASSISTANCE OF ERMA FLAHERTY \\ (From the Pulmonary Function Laboratories, Departments of Medicine, Wayne State University \\ College of Medicine, and City of Detroit Receiving Hospital, Detroit, Mich.)
}

(Submitted for publication February 18, 1959; accepted June 19, 1959)

The pulmonary diffusing capacity for oxygen $\left(\mathrm{DL}_{\mathrm{O}_{2}}\right)$ is of great physiological and clinical significance (1). Its measurement, however, is relatively complex (2). Pulmonary diffusing capacity for carbon monoxide (DLco) which, it is usually assumed, ${ }^{1}$ can be converted to $\mathrm{DL}_{\mathrm{O}_{2}}$ from the known solubilities and molecular weights of the two gases, is, in general, more readily measured. Further, since the rate of reaction of carbon monoxide with hemoglobin has been measured (4) in vitro while that of oxygen has not, determination of DLco at two or more alveolar oxygen tensions makes possible the computation of pulmonary capillary blood volume and pulmonary membrane diffusing capacity $(5-7)$.

The methods used for measuring $\mathrm{DL}_{\mathrm{CO}}$ are the single breath technique of Krogh (8) as modified by Ogilvie, Forster, Blakemore and Morton (9), the steady state technique using an independent measurement of the physiological dead space (10), the steady state technique using an alveolar sample (11) and a rebreathing technique using $\mathrm{C}^{14} \mathrm{O}$ (12). The present paper presents a modification of the rebreathing method utilizing stable $\mathrm{CO}$ and continuous analysis.

\section{METHODS}

A. Experimental procedure. The apparatus shown in Figure 1 was used in these studies. The subject's vital

* This work was presented, in part, before the spring meeting of the American Physiological Society in Philadelphia, April 18, 1958, and before the annual meeting of the American Federation for Clinical Research in Atlantic City, May 4, 1958.

$\dagger$ This work was supported by grants from the Receiving Hospital Research Corporation, the National Heart Institute (Grant H-2379) and the Michigan Heart Association.

$\ddagger$ This work was performed while a Fellow of the Rands Foundation.

$\S$ Research Fellow of the Michigan Heart Association.

1 This assumption has recently been challenged by Bates capacity and one second vital capacity are first determined. The analyzer circuit of the apparatus is then flushed with tank oxygen. A sealed bag containing a volume of 0.3 per cent $\mathrm{CO}$ and 10 per cent $\mathrm{He}$ in air (or in oxygen) ${ }^{2}$ equal to the subject's one second vital capacity is attached to the three-way tap, the clamps on the bag are removed and the bag and analyzer circuit mixed by the pump. ${ }^{3}$ A bag-in-box device attached to a spirometer has been found convenient for filling the bag. The subject then expires fully through the open arm of the three-way tap, following which the tap is turned to connect him with the bag. The subject rebreathes into the bag for 30 to 45 seconds at a rate of 30 cycles per minute in time to a metronome, endeavoring to empty the bag on each inspiration. At the end of this period the tap is closed, the pump is stopped and the bag clamped and removed. Before and after the measurement of diffusing capacity the equilibrium pCO of the subject's blood is determined by a rebreathing technique (13). The bag is then analyzed for oxygen, carbon dioxide and helium by passing its contents successively through a paramagnetic oxygen analyzer, ${ }^{4}$ an infrared $\mathrm{CO}_{2}$ analyzer ${ }^{5}$ and a katharometer. ${ }^{6}$ Carbon dioxide is adsorbed before the sample is passed through the katharometer.

$B$. Calculations. The volume of the lung-bag system is calculated from the equation:

$$
V_{\mathrm{s}}=\frac{\mathrm{F}_{\mathrm{b}} \mathrm{V}_{\mathrm{b}}}{\mathrm{F}_{\mathrm{s}}}
$$

where $V_{s}=$ volume of the lung-bag system in milliliters STPD, $V_{b}=$ volume of rebreathing bag in milliliters STPD, $F_{b}=$ concentration of helium in the bag at start of rebreathing and $F_{s}=$ concentration of helium in bag at end of rebreathing. $V_{b}$ is obtained from the record of the spirometer attached to the bag-in-box from which the bag is filled. $\quad F_{b}$ and $F_{B}$ are determined by katharometer analysis of the gas mixture used and of the bag contents at the end of rebreathing. Since $\mathrm{CO}_{2}$ is absorbed before the gas is passed through the katharometer, this last reading is multiplied by $1-\frac{\text { per cent } \mathrm{CO}_{2}}{100}$ to obtain the final helium concentration.

\footnotetext{
${ }^{2}$ Matheson Co., E. Rutherford, N. J.

${ }^{3}$ Dyna-Pump, Fisher Scientific Co., Pittsburgh, Pa.

${ }^{4}$ Model E2, Beckman Instrument Co., Pasadena, Calif.

5 Model 16, Liston Becker Division, Beckman Instruments, Fullerton, Calif.

${ }^{6}$ Cambridge Instrument Co., New York, N. Y.
} 
The subject's residual volume may readily be calculated by subtracting the volume of the bag and the dead space of the apparatus $(150 \mathrm{ml}$.) from the total volume thus obtained.

The $\mathrm{CO}$ concentration during rebreathing is recorded by a direct writing oscillograph moving at $1 \mathrm{~cm}$. per second. This record is measured at any desired interval, usually five seconds. From this measured deflection is subtracted the deflection produced by passing 5 per cent $\mathrm{CO}_{2}$ through the $\mathrm{CO}$ analyzer. In two subjects the error introduced by the use of a standard correction for $\mathrm{CO}_{2}$ was investigated by placing an infrared $\mathrm{CO}_{2}$ analyzer in the circuit and recording simultaneously $\mathrm{CO}$ and $\mathrm{CO}_{2}$ concentration in the bag. Each point of the $\mathrm{CO}$ record could then be corrected for the deflection due to the $\mathrm{CO}_{2}$ present at that point by using a calibration curve for the sensitivity of the $\mathrm{CO}$ analyzer to $\mathrm{CO}_{2}$. The points thus obtained were indistinguishable from those obtained by using a standard correction.

After the measured points are corrected for $\mathrm{CO}_{2}$, the $\mathrm{CO}$ concentrations are read from a calibration curve and these values are corrected for the back pressure of $\mathrm{CO}$ in the pulmonary capillaries. The back pressure is calculated by interpolating between the initial and final equilibrium $\mathrm{CO}$ values obtained as described above and multiplying this interpolated value by the fraction $\mathrm{pO}_{2}$ (bag) $/ \mathrm{pO}_{2}$ (equilibrium sample). This correction is only approximate since it assumes that all hemoglobin $(\mathrm{Hb})$ is in the form $\mathrm{O}_{2} \mathrm{Hb}$.

After this final correction, the values for $\mathrm{CO}$ concentration are plotted against time on semilogarithmic paper. A line is drawn through the points beginning with the final concentration. From this line, values for $\mathrm{CO}$ concentration at any convenient time interval are obtained and substituted into Krogh's equation (8):

$$
\mathrm{D}=\frac{\mathrm{V}_{\mathrm{s}}}{\mathrm{Pb}\left(\mathrm{t}_{2}-\mathrm{t}_{1}\right)} \ln \frac{\mathrm{Fs}_{\mathrm{t}_{1}}}{\mathrm{Fs}_{\mathrm{s}_{2}}},
$$

where $\mathrm{F}_{\mathrm{s}_{1}}=$ concentration of $\mathrm{CO}$ (dry) in the lung bag system at time $\mathrm{t}_{1}, \mathrm{Fs}_{\mathrm{t}_{2}}=$ concentration of $\mathrm{CO}(\mathrm{dry})$ in the lung bag system at time $\mathrm{t}_{2}, \mathrm{D}=\mathrm{D}_{\mathrm{L}_{\mathrm{CO}}}=$ apparent diffusing capacity of the lungs for $\mathrm{CO}$ in milliliters per millimeter $\mathrm{Hg} \times$ minute, $\mathrm{Pb}=$ pressure of the dry gases in the lungbag system, $\left(t_{2}-t_{1}\right)=$ time of rebreathing in minutes and $\mathrm{ln}=$ natural logarithm.

C. Other methods. Vital capacity and one second vital capacity were measured by a rapidly moving spirometer kymograph. $^{7}$ Residual volume was measured as described above or by a closed circuit helium method (14). Maximum breathing capacity was measured with the use of a high velocity valve ${ }^{8}$ and a $120 \mathrm{~L}$. Tissot type spirometer. The single breath diffusing capacity was measured as described by Ogilvie and co-workers (9). The steady state diffusing capacity was measured by the method of Filley, MacIntosh and Wright (10); $\mathrm{PacO} 2$ was obtained from direct measurement of $\mathrm{CO}_{2}$ content and $\mathrm{pH}$ by the use of nomogram (15). Arterial oxygen saturation was measured as described by Peters and Van Slyke (16).

\section{RESULTS}

The absorption of $\mathrm{CO}$ was measured continuously during a 30 to 45 second period of rebreathing 578 times in 128 subjects. In 571 studies (98.9 per cent) the disappearance of $\mathrm{CO}$ was apparently exponential for a period of 15 seconds or more. The exponential fall of $\mathrm{CO}$ began within the first five seconds of rebreathing in 236 studies (40.8 per cent), between six and 10 seconds in 229 studies ( 39.6 per cent), between 11 and 15 seconds in 80 instances ( 13.8 per cent) and between 16 and 20 seconds in 23 studies (4.0 per cent), 19 of which were of 45 seconds' duration and four of 35 seconds' duration. In four studies ( 0.7 per cent), all of 45 seconds, the

${ }^{7}$ H. S. Osborne, Havertown, Pa.

${ }^{8}$ Hans Rudolph, Kansas City, Mo.

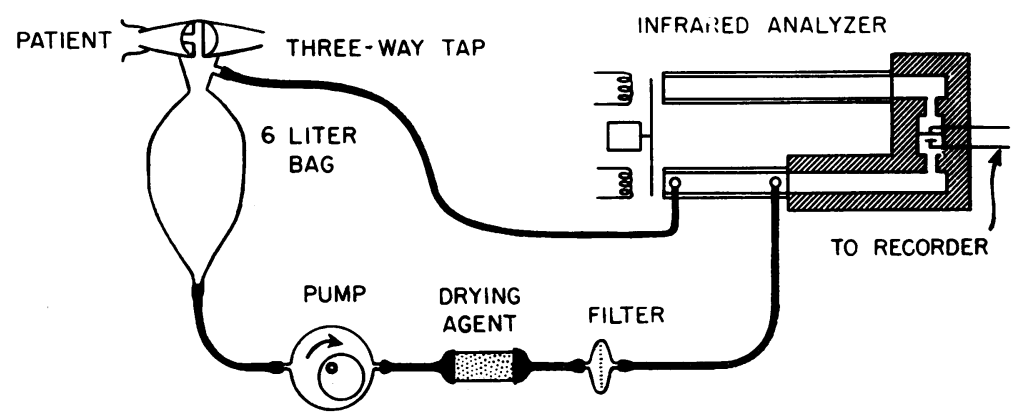

Fig. 1. Diagram of Appakatus for Meascring Pclmonary Diffesing; CAPACITY BY REBREATHING

The pump circulates the contents of the bag through the drying agent (anhydrous $\left.\mathrm{CaSO}_{4}\right)$, filter (Kel-F ${ }^{\circledR}$, Liston-Becker Division, Beckman Instruments Inc.) and infrared $\mathrm{CO}$ analyzer (Model 15A, Beckman Instruments, Inc.) at the rate of $3 \mathrm{~L}$. per minute. Volume of analyzer circuit is $150 \mathrm{ml}$. Inner diameter of openings to analyzer is one-eighth inch. Pressure at mouth during operation of pump is $0.3 \mathrm{~cm}$. $\mathrm{H}_{2} \mathrm{O}$. 
He mixing and $\mathrm{CO}$ absorbtion during rebreothing

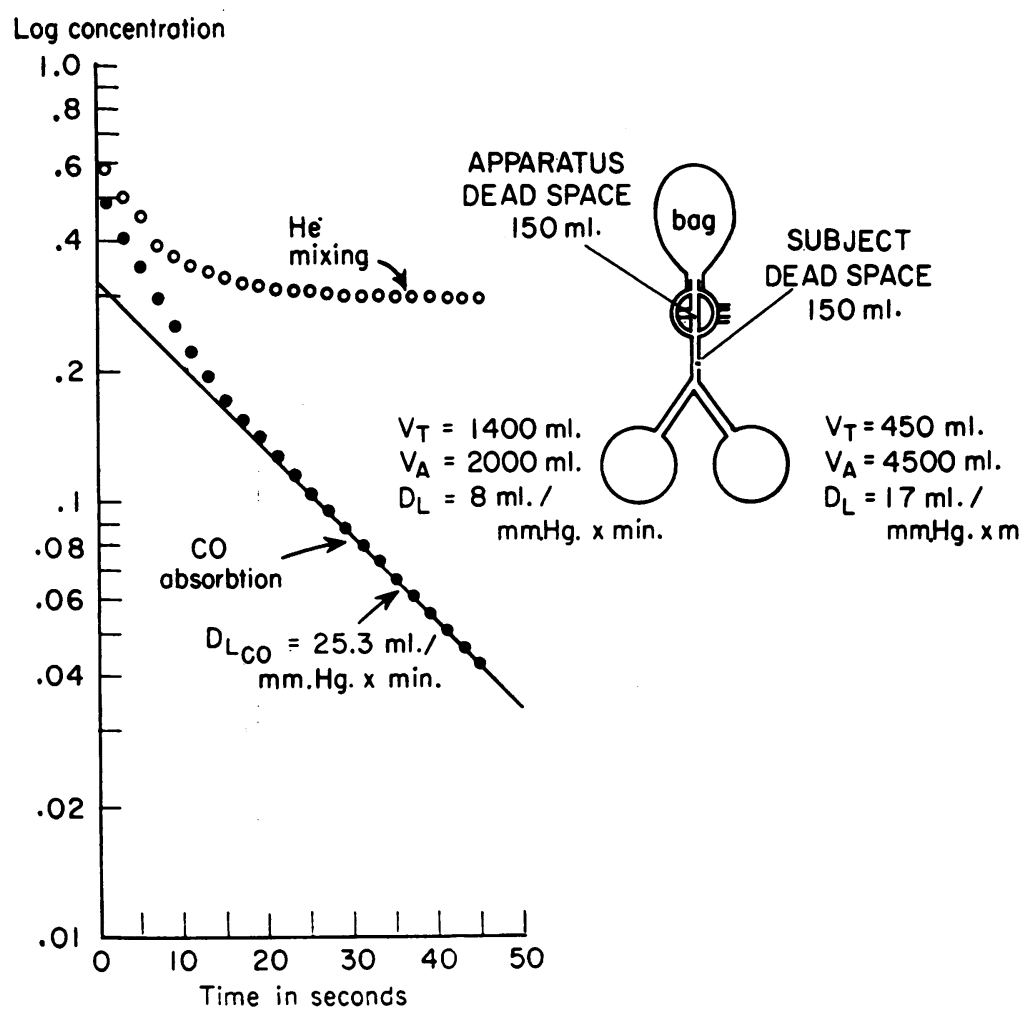

Fig. 2. Helium Mixing and Carbon Monoxide Absorption DURing REBREATHING

The concentrations of helium and $\mathrm{CO}$ are computed breath by breath for a 45 second period of rebreathing at 30 cycles per minute for the lung model shown at right. For explanation of abbreviations and comparison of different methods for measuring diffusing capacity in this lung model, see Table IV.

fall of $\mathrm{CO}$ was exponential after 21 to 25 seconds of rebreathing. When this apparently exponential decrease did not begin with the first measured point, the plot of $\log \mathrm{CO}$ concentration prior to this time showed a gradually decreasing slope similar to that illustrated in Figure 2. This is probably due to concurrent mixing of the bag and the alveoli and diffusion from the alveoli into the blood. Those subjects in whom 10 seconds or more of rebreathing elapsed before $\mathrm{CO}$ concentration began to fall in an exponential manner usually had emphysema.

The continuous sampling method used in these studies was compared with discrete sampling at three points in five studies in four normal subjects (Table I). For each subject, three bags were filled to the same volume. The subject rebreathed into these bags for accurately timed periods of approximately 10, 20 and 30 seconds.
The final CO concentration in each bag was measured, plotted against time and DLCo calculated from the line connecting these points. As shown in Table I, this method of sampling did not give results significantly different from con-

TABLE I

\begin{tabular}{ccc} 
Effect of sampling method on $D_{L_{C O}}{ }^{*}$ \\
$\begin{array}{c}\text { DLCo } \\
\text { Continuous } \\
\text { sample }\end{array}$ & $\begin{array}{c}\text { DLCo } \\
\text { Discrete } \\
\text { sample }\end{array}$ \\
\hline Subject & 28.8 & 28.6 \\
E. S. C. & 35.4 & 34.7 \\
J. M. & 16.1 & $15.4 \dagger$ \\
R. G. & 28.2 & 26.9 \\
Average $\neq$ & 37.1 & 37.5 \\
& 29.13 & 28.63
\end{tabular}

* $\mathrm{D}_{\mathrm{LCO}}=$ apparent diffusing capacity of lung for $\mathrm{CO}$ in milliliters per millimeter $\mathrm{Hg} \times$ minute.

$\dagger \mathrm{pO}_{2} 600 \mathrm{~mm}$. $\mathrm{Hg}$; other studies $\mathrm{pO}_{2} 100 \mathrm{~mm}$. $\mathrm{Hg}$.

$\ddagger$ Average of five studies. 
Effect of increosing bog volume on $D_{L_{c O}}$ Normal subjects

$D_{\text {LO }} \mathrm{ml} . / \mathrm{mmHg} \times \mathrm{min}$.

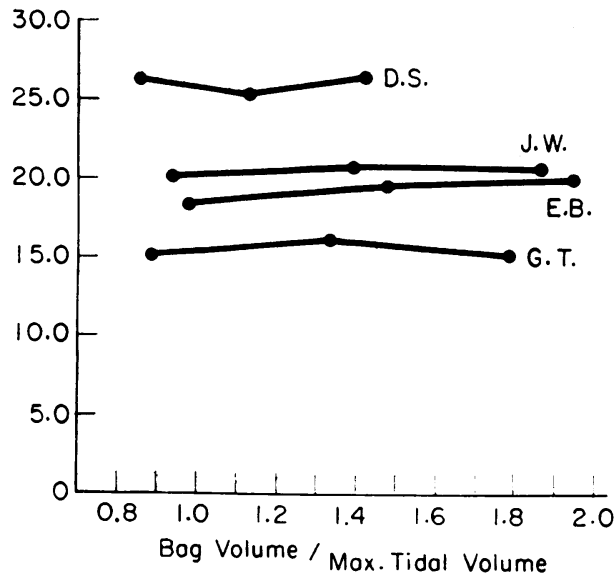

Fig. 3. EfFect of Increasing Bag Volume oN Diffusing Capacity in Normal Subjects

tinuous analysis of the bag during a 30 second period.

The effect of increasing the apparatus dead space was studied in four normal subjects and five patients with emphysema by putting a greater volume in the rebreathing bag than the subject could inspire. For normal subjects the maximum tidal volume was assumed to be the one second vital capacity. Bag volumes greater than the one second vital capacity, then, represented an increase in apparatus dead space. As shown in Figure 3, such an increase did not change DLCo.

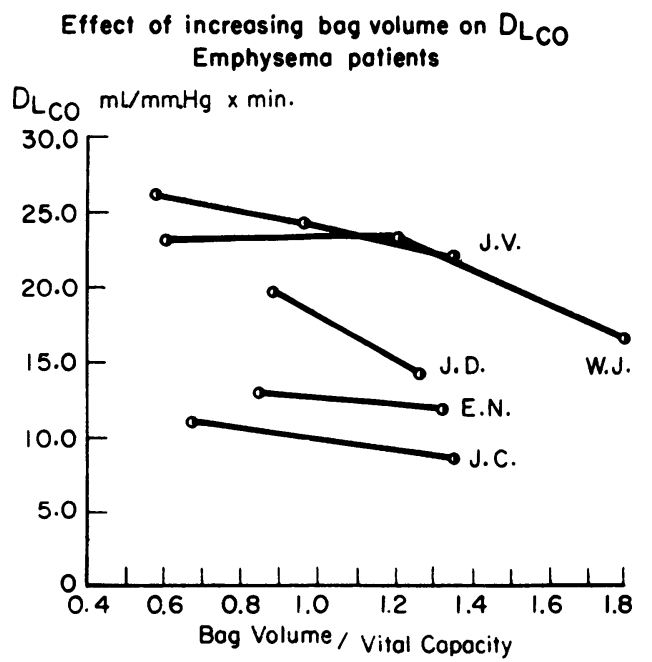

Fig. 4. Effect of Increasing Bag Volume on Diffusing Capacity in Patients with Emphysema

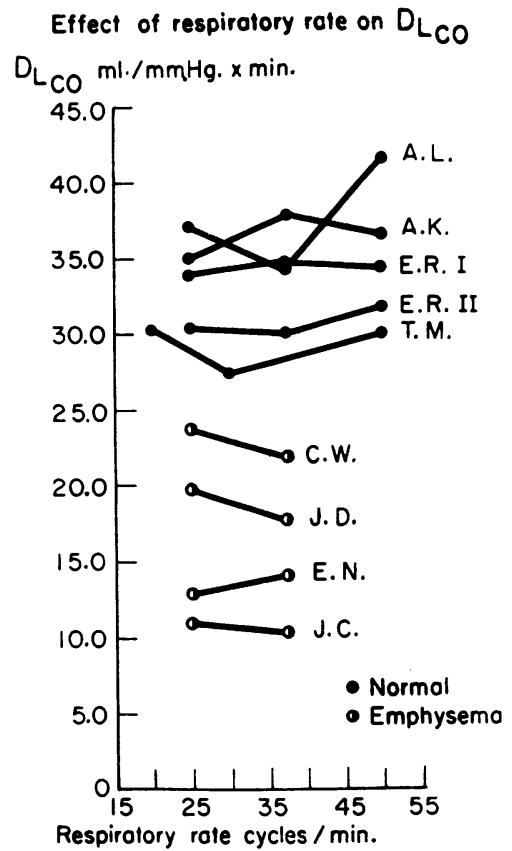

Fig. 5. EFfect of Rate of Rebreathing on Diffl'sing Capacity

This experiment was modified for the patients with emphysema. Previous experience with these patients had shown that when a volume of gas slightly less than the vital capacity was placed in the bag, the patient, after several

Effect of decreosing bog volume on $D_{L}$ co

$D_{\text {LO }} \mathrm{ml} / \mathrm{mmHg} \times \mathrm{min}$.

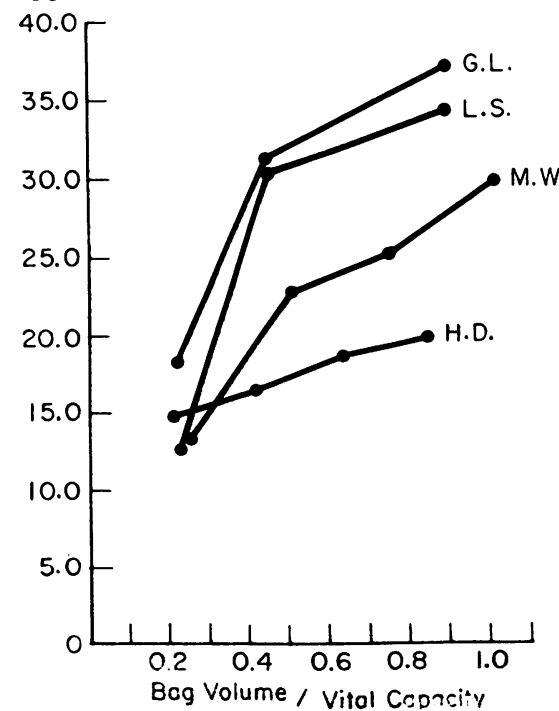

Fig. 6. EfFect of Decreasing Bag Volume on Diffusing Capacity in Normal Subjects 
breaths, 'emptied the bag completely on inspiration and yet had a tidal volume approximating his one second vital capacity. When the bag volume was appreciably less than the vital capacity, the tidal volume became very small because of air trapping during rapid expiration. There- fore, to increase the apparatus dead space, volumes of gas greater than the total vital capacity were placed in the bag. As shown in Figure 4, this led to lower values for calculated DLCo.

The effect of changing rebreathing rate at the same bag volume was studied five times in four

TABLE II

Diffusing capacity of lungs in normal subjects (males)

\begin{tabular}{|c|c|c|c|c|c|c|c|c|}
\hline \multirow[b]{2}{*}{ Subject } & \multirow[b]{2}{*}{ Age } & \multirow[b]{2}{*}{$\mathrm{Ht}$. } & \multirow[b]{2}{*}{ Wt. } & \multirow[b]{2}{*}{ BSA* } & \multirow[b]{2}{*}{ VC } & \multicolumn{3}{|c|}{$\mathrm{D}_{\mathbf{L}} \mathbf{C O}$} \\
\hline & & & & & & RB & SB & SS \\
\hline & yrs. & in. & lbs. & $M .2$ & $m l$. & \multicolumn{3}{|c|}{$m l . / m m . H g \times m i n$} \\
\hline H. B. & 19 & 69 & 152 & 1.84 & 4,020 & 26.7 & 32.9 & 21.2 \\
\hline L. McL. & 26 & 67 & 159 & 1.84 & 4,280 & 26.8 & 27.1 & \\
\hline M. N. & 15 & 68 & 121 & 1.65 & 3,692 & 23.2 & 28.3 & \\
\hline & 16 & 68 & 129 & 1.69 & 3,695 & 28.8 & 30.2 & \\
\hline & 31 & 67 & 135 & 1.72 & 3,460 & 15.6 & 18.7 & \\
\hline & 20 & 71 & 139 & 1.80 & 4,210 & 28.6 & 24.5 & \\
\hline & 20 & 68 & 126 & 1.69 & 3,830 & 22.0 & 31.3 & 16.5 \\
\hline E. C. & 31 & 73 & 178 & 2.06 & 5,025 & 35.4 & 34.8 & \\
\hline & 20 & 67 & 128 & 1.67 & 3,665 & 22.8 & 24.3 & \\
\hline & 32 & 66 & 142 & 1.75 & 4,035 & 18.2 & 19.9 & \\
\hline & 39 & 69 & 172 & 1.94 & 2,998 & 18.9 & 22.9 & \\
\hline & 16 & 64 & 178 & 1.86 & 3,280 & 21.7 & 29.9 & \\
\hline & 29 & 66 & 136 & 1.70 & 2,918 & 20.5 & 21.1 & \\
\hline & 24 & 70 & 166 & 1.93 & 4,180 & 24.6 & 28.0 & 15.1 \\
\hline & 25 & 74 & 186 & 2.11 & 4,800 & 37.5 & 35.0 & \\
\hline T. M. & 25 & 68 & 168 & 1.91 & 5,419 & 27.5 & 35.5 & \\
\hline W. H. & 47 & 71 & 151 & 1.88 & 3,760 & 21.9 & 21.8 & 18.5 \\
\hline W. S. & 15 & 67 & 137 & 1.73 & 4,460 & 19.6 & 24.6 & 16.4 \\
\hline & 18 & 70 & 145 & 1.83 & 4,700 & 33.2 & 32.0 & \\
\hline & 29 & 68 & 185 & 1.98 & 4,270 & 23.1 & 28.6 & \\
\hline & 31 & 73 & 209 & 2.20 & 4,300 & 26.3 & 32.8 & \\
\hline & 20 & 71 & 162 & 1.93 & 4,000 & 26.8 & 02.0 & \\
\hline B. & 15 & 70 & 150 & 1.85 & 4,720 & 30.9 & 25.3 & \\
\hline & 30 & 73 & 185 & 2.09 & 4,130 & 34.4 & & \\
\hline & 18 & 65 & 150 & 1.76 & 4,112 & 37.0 & & \\
\hline M. W. & 21 & 70 & 148 & 1.84 & 3,620 & 29.7 & & \\
\hline & 32 & 72 & 159 & 1.93 & 4,346 & 19.8 & & \\
\hline & 23 & 67 & 130 & 1.68 & 3,580 & 25.0 & 26.7 & \\
\hline & 19 & 70 & 136 & 1.78 & 3,195 & 18.2 & 17.8 & \\
\hline W. L. & 33 & 74 & 187 & 2.11 & 4,890 & 40.4 & 41.2 & \\
\hline E. R. & 24 & 72 & 188 & 2.07 & 5,640 & 32.1 & & \\
\hline J. McG. & 31 & 72 & 155 & 1.91 & 5,500 & 28.2 & & \\
\hline A..Z. & 23 & 73 & 205 & 2.18 & 5,150 & 30.5 & & \\
\hline $\mathrm{R}$ & 25 & 73 & 180 & 2.06 & 4,935 & 37.1 & & \\
\hline A. & 23 & 69 & 158 & 1.91 & 5,000 & 35.1 & & \\
\hline & 24 & 71 & 160 & 1.92 & 5,104 & 37.1 & & \\
\hline \multicolumn{2}{|l|}{ Average } & 69.62 & 158.20 & 1.88 & 4,157 & 27.3 & & \\
\hline \multicolumn{9}{|c|}{ Diffusing capacity of lungs in normal subjects (females) } \\
\hline & 32 & 60 & 111 & 1.45 & 3,000 & 18.5 & 24.0 & \\
\hline & 30 & 66 & 134 & 1.69 & 3,100 & 15.3 & & \\
\hline J. W. & 38 & 66 & 200 & 2.01 & 2,600 & 20.2 & & \\
\hline E. B. & 26 & 67 & 116 & 1.60 & 3,500 & 18.4 & & \\
\hline L. B. & 30 & 65 & 125 & 1.62 & 3,050 & 18.7 & & \\
\hline S. H. & 20 & 62 & 103 & 1.45 & 2,830 & 19.4 & & \\
\hline F. A. & 23 & 65 & 127 & 1.62 & 3,725 & 25.8 & & \\
\hline U. B. & 28 & 64 & 160 & 1.78 & 3,003 & 26.5 & & \\
\hline W. G. & 35 & 64 & 135 & 1.65 & 2,585 & 18.3 & & \\
\hline M. R. & 22 & 67 & 137 & 1.73 & 2,794 & 21.3 & & \\
\hline & 32 & 64 & 134 & 1.65 & 2,330 & 14.4 & & \\
\hline \multicolumn{2}{|l|}{ Average } & 64.55 & 134.73 & 1.66 & 2,956 & 19.7 & & \\
\hline
\end{tabular}

* Body surface area. 
TABLE III

Diffusing capacity of the lungs in disease

\begin{tabular}{|c|c|c|c|c|c|c|c|c|c|c|c|c|c|c|c|}
\hline \multirow[b]{2}{*}{ Patient } & \multirow[b]{2}{*}{ Diagnosis } & \multirow[b]{2}{*}{ Age } & \multirow[b]{2}{*}{ Sex } & \multirow[b]{2}{*}{ Ht. } & \multirow[b]{2}{*}{ Wt. } & \multirow[b]{2}{*}{ BS.I } & \multirow[b]{2}{*}{$\mathrm{VC}$} & \multirow[b]{2}{*}{$\mathrm{RV}^{*}$} & \multirow[b]{2}{*}{$1^{\prime \prime} \mathrm{VC}$} & \multirow[b]{2}{*}{$\mathrm{MBC}$} & \multirow[b]{2}{*}{$\mathrm{S}_{\mathrm{AO}_{2}}$} & \multirow[b]{2}{*}{$\mathrm{PaCO}_{2}$} & \multicolumn{3}{|c|}{$\mathrm{D}_{L_{C O}}$} \\
\hline & & & & & & & & & & & & & $\mathrm{RB}$ & $\mathrm{SB}$ & ss \\
\hline & & $y r s$ & & $i n$ & lbs. & $M .^{2}$ & $m l$. & $m l$. & $\%$ & L./min. & $\%$ & $m m . H g$ & $m l . / m$ & n. $H g \times$ & min. \\
\hline H. K. & Emphysema & 52 & M & 64 & 159 & 1.78 & 1,134 & 3,355 & 41 & & 79 & 49 & 22.6 & & 5.5 \\
\hline R. O. & Emphysema & 73 & $\mathrm{M}$ & 66 & 131 & 1.68 & 2,630 & 3,325 & 53 & 53 & 70 & +2 & 24.1 & & \\
\hline D. W. & Emphysema & 44 & M & & 126 & & 1,940 & 2,686 & 60 & & & & 16.7 & 17.5 & \\
\hline P. B. & Emphysema & 46 & $\mathrm{M}$ & 71 & 170 & 1.97 & 1,980 & 5,075 & 27 & 33.6 & 95 & 41 & 29.5 & 36.9 & \\
\hline E. R. & Emphysema & 52 & M & 67 & 167 & 1.87 & 3,000 & 2,377 & 33 & & 73 & 69 & 21.8 & 28.8 & 10.0 \\
\hline J. U. & Emphysema & 68 & $\mathrm{M}$ & 68 & 160 & 1.85 & 2,640 & 2,977 & 42 & 52 & 96 & 34 & 26.1 & 19.0 & \\
\hline S. P. & Emphysema & 64 & M & 68 & 140 & 1.77 & 2,740 & 3,980 & 42 & & 96 & 30 & 19.7 & 14.0 & \\
\hline W. J. & Emphysema & 57 & $\mathrm{M}$ & 72 & 103 & 1.61 & 1,685 & 5,420 & 38 & & & & 23.3 & 16.9 & \\
\hline R. J. & Emphysema & 53 & $\mathrm{M}$ & & & & 1,762 & 2,244 & 50 & 37 & 94 & 36 & 20.7 & 24.6 & \\
\hline J. Y. & Emphysema & 56 & $\mathrm{M}$ & 72 & 111 & 1.66 & 1,820 & 4,800 & 32 & & 90 & 52 & 19.1 & & \\
\hline J. D. & Emphysema & 65 & $\mathrm{M}$ & 66 & 97 & 1.47 & 2,686 & 3,430 & 30 & 26 & 91 & 50 & 18.7 & & \\
\hline N.F. & Emphysema & 59 & M & 74 & 183 & 2.09 & 2,166 & 4,250 & 38 & & & & 13.4 & & \\
\hline C. W. & Emphysema & 50 & $\mathrm{M}$ & 69 & 125 & 1.71 & 3,219 & 5,150 & 28 & 47 & & & 23.7 & & \\
\hline E. N. & Emphysema & 78 & $\mathrm{M}$ & 71 & 123 & 1.72 & 2,131 & 3,258 & 27 & & 95 & 39 & 14.0 & & \\
\hline G. V. & Emphysema & 63 & $\mathrm{M}$ & 66 & 140 & 1.73 & 2,238 & 3,177 & 29 & 25 & & & 13.0 & 9.5 & \\
\hline C.S. & Emphysema & 39 & $\mathrm{M}$ & 74 & 118 & 174 & 3,512 & 3,580 & 26 & 52 & & & 19.4 & & \\
\hline J. C. & Emphysema & 74 & $\mathrm{M}$ & 64 & 104 & 1.48 & 1,775 & 3,276 & 43 & 29 & & & 11.0 & & \\
\hline iV. M. & $\begin{array}{l}\text { Emphysema, } \\
\text { bullous }\end{array}$ & 70 & $\mathrm{M}$ & 65 & 155 & 1.77 & 1,977 & 3,480 & 43 & & 95 & 38 & 21.6 & 25.8 & 22.3 \\
\hline W. F. & $\begin{array}{c}\text { Emphysema, } \\
\text { bullous }\end{array}$ & 57 & $\mathrm{M}$ & 67 & 110 & 1.58 & 1,985 & 2,021 & 41 & & 85 & 44 & 9.0 & 8.2 & \\
\hline D. B. & Sarcoid & 23 & $\mathrm{M}$ & 74 & 144 & 1.89 & 1,745 & 584 & 75 & 80.6 & 88 & 3.3 & 8.9 & 13.7 & \\
\hline M. B. & Sarcoid & 24 & $\mathrm{M}$ & 67 & 126 & 1.66 & 1,250 & 682 & 100 & 123 & 98 & 37 & 9.4 & 12.8 & 13.0 \\
\hline W.S. & Sarcoid & 32 & $\mathrm{M}$ & 69 & 196 & 2.05 & 2,550 & 1,156 & 78 & & 98 & 36 & 18.5 & 28.0 & 12.6 \\
\hline J.S. & Sarcoid & 36 & $\mathrm{M}$ & 68 & 140 & 1.76 & 3,478 & 1,151 & 88 & & 98 & 36 & 24.4 & 21.7 & 27.6 \\
\hline W. Se & Fibrosis & 64 & M & 66 & 177 & 1.89 & 1,506 & 1,024 & 73 & 81 & 92 & 34 & 6.0 & & \\
\hline E. J. & Radiation fibrosis & 57 & $\mathrm{~F}$ & 63 & 119 & 1.56 & 2,450 & 1,482 & 52 & 67 & & & 17.2 & & \\
\hline A. P. & Calcification & 72 & $\mathrm{M}$ & 69 & 1.37 & 1.76 & 3,435 & 2,850 & 60 & 6.3 .4 & & & 7.7 & & \\
\hline R. J. & Anemia & 45 & $\mathrm{M}$ & 70 & 147 & 1.84 & 3,655 & 1,210 & 81 & & & & 11.9 & 13.8 & \\
\hline W.Sh & Anemia & 38 & $\mathrm{~F}$ & 62 & 156 & 1.74 & 2,474 & 790 & 76 & & & & 10.9 & 14.7 & \\
\hline S.S. & Polycythemia & 50 & $\mathrm{M}$ & 70 & 163 & 1.92 & 4,080 & 1,747 & 80 & & 98 & 35 & 24.0 & 37.3 & 13.4 \\
\hline G. G. & Tuberculosis & 51 & $\mathrm{M}$ & 68 & 152 & 1.82 & 3,790 & 2,015 & 71 & 134 & 98 & 30 & 21.6 & 24.0 & \\
\hline L. D. & Obesity & 42 & $\mathrm{~F}$ & 68 & 329 & 2.52 & 1,640 & 988 & 76 & & & & 20.1 & & \\
\hline H. B. & Barrel chest & 66 & M & 74 & 190 & 2.00 & 5,905 & 2,250 & 76 & 133 & & & 26.3 & & \\
\hline F. H. & Hypertension & 65 & M & 72 & 194 & 2.10 & 3,380 & 1,976 & 77 & 71 & 96 & 33 & 20.0 & 22.6 & \\
\hline J.Sh & Mitral stenosis & 28 & $\mathrm{~F}$ & 65 & 143 & 1.72 & 1,284 & 1,427 & & & & & 12.6 & 13.1 & \\
\hline
\end{tabular}

* Abbreviations are as follows: $\mathrm{RV}$, residual volume; $1^{\prime \prime} \mathrm{VC}$, one second vital capacity as per cent of total; MBC, maximum breathing capacity; $\mathrm{SaO}_{2}$, arterial oxygen saturation; $\mathrm{PaCO}_{2}$, arterial $\mathrm{CO}_{2}$ tension. Other abbreviations are as in previous tables. $\mathrm{IC}$ and MBC are measured at BTPS; other volumes are measired at STPD.

normal subjects and in four patients with emphysema (Figure 5). Variance analysis of the data for normal subjects showed no significant difference among the rates studied. Three of the four patients showed a lower value for $\mathrm{DL}_{\mathrm{LO}}$ at the higher rate.

The effect of decreasing bag volume below the vital capacity was studied in four normal subjects (Figure 6). There is a marked decrease in calculated D $\mathrm{L}_{\mathrm{CO}}$ when the bag volume was about 25 per cent of the vital capacity, i.e., when the total volume of the lung-bag system approximated the subject's functional residual capacity.

Our data on the rebreathing $\mathrm{DL}_{\mathrm{Co}}$ in 47 subjects free from heart, lung or hematologic disease are shown in Table II. Data for the single breath $\mathrm{DL}_{\mathrm{CO}}$ are available in 26 of these subjects and for the steady state DLCo in five. In all cases, the rebreathing DLCo $_{\mathrm{Co}}$ was measured in the seated position, the gas breathed was approximately 0.3 per cent $\mathrm{CO}$ in air and the bag volume was equal to the one second vital capacity. Measurements of single breath and steady state DLCo were made on the same day in the seated position. The lung volume for the single breath measurement was full inspiration and for the steady state determination, functional residual capacity. The rebreathing DLCo was significantly related to the height $(r=0.624)$, weight $(r=$ $0.506)$, body surface area $(r=0.603)$ and vital capacity $(r=0.732)$. The regression equations for these relations are: DI.co $=1.265$ height (in.) $-60.98 \pm 5.28 ; \mathrm{DL}_{\mathrm{CO}}=0.1361$ weight (lbs.) + $4.79 \pm 5.74 ; \mathrm{DL}_{\mathrm{CO}}=22.77$ body surface area 
$\left(M .^{2}\right)-16.11 \pm 5.39$ and $D_{L_{C O}}=5.92$ vital capacity (L.) $+2.22 \pm 4.61$.

The coefficient of variation in 35 duplicate determinations of $\mathrm{DL}_{\mathrm{Co}}$ in normal subjects was 6.1 per cent.

Since these subjects were young adults, no conclusions as to the relation of D $\mathrm{L}_{\mathrm{CO}}$ to age can be drawn from our data.

Data on 34 patients with pulmonary, cardiac or hematologic disease are shown in Table III. Except for the emphysematous patients, measurements of DLCo were carried out as in normal subjects. In the emphysematous patients, bag volume was approximately equal to total vital capacity, rather than one second vital capacity. Additional clinical data on these patients are found in Appendix I.

In 13 duplicate determinations of $\mathrm{DL}_{\mathrm{CO}}$ in patients without airway obstruction, the coefficient of variation was 5.3 per cent. In 11 duplicate determinations in patients with emphysema, the coefficient of variation was 9.2 per cent.

Figure 7 shows a comparison of the rebreathing and single breath measurements of DLCo in 26 normal subjects, 10 patients without airway ob-

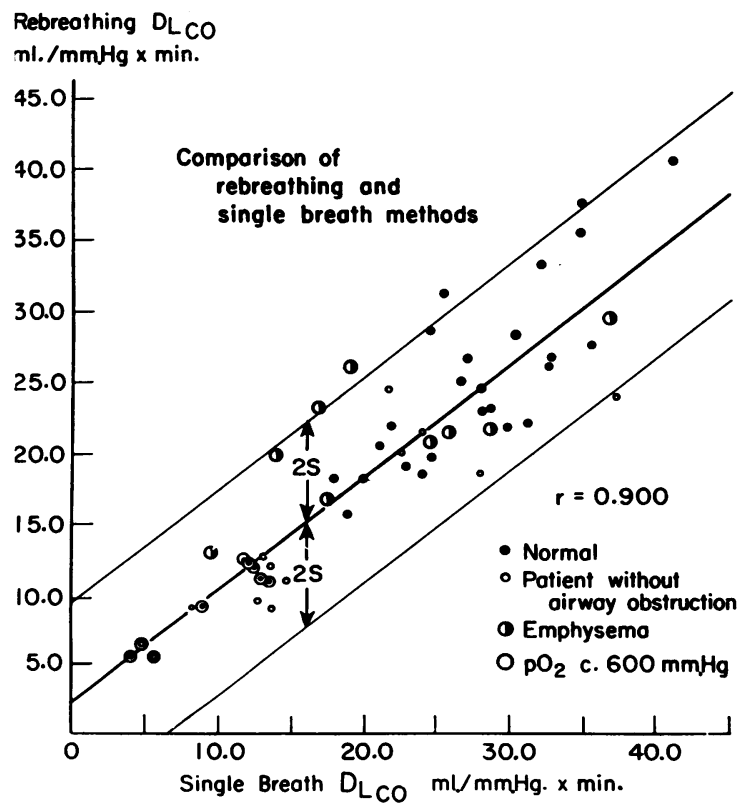

Fig. 7. Comparison of Measurements of Diffusing Capacity by Rebreathing and Single Breath Methods

The equation of the regression line is $\mathrm{D}_{\mathrm{L}}$ (rebreathing) $=0.793 \mathrm{D}_{\mathrm{LCO}_{\mathrm{CO}}}$ (single breath) $+2.36 \pm 3.68$. " $\mathrm{S}$ " is the standard error of the estimate of this equation.
Comparison of rebreathing and steady state methods

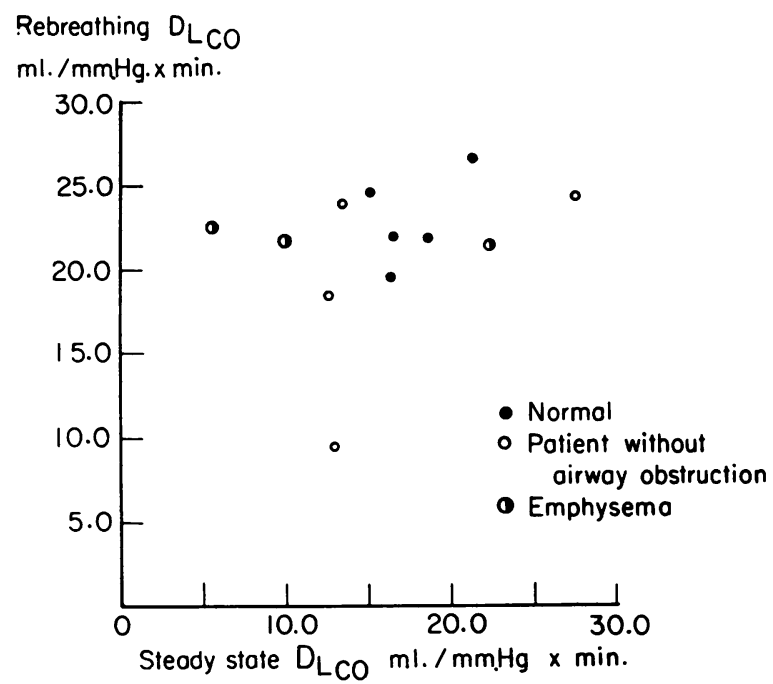

Fig. 8. Comparison of Measurements of Diffusing Capacity by Rebreathing and Steady State Methods

struction and 10 patients with emphysema. Also shown are comparisons of rebreathing and single breath $\mathrm{DL}_{\mathrm{CO}}$ at an alveolar $\mathrm{pO}_{2}$ of about $600 \mathrm{~mm}$. $\mathrm{Hg}$ in four normal subjects and five patients without airway obstruction. The regression line is for the data on normal subjects and patients without airway obstruction. As discussed below, different theoretical considerations apply to the measurement of $\mathrm{DL}_{\mathrm{CO}}$ by rebreathing in emphysematous patients.

Figure 8 shows a similar comparison of the steady state and rebreathing measurements of DL $_{\text {Co }}$ for five normal subjects, four patients without airway obstruction and three patients with emphysema. No relation between the two measurements is evident from the rather few data available.

In Figure 9 the residual volume calculated from rebreathing data as explained above is compared with the residual volume determined in duplicate by the closed circuit helium method (14) in 28 normal subjects, 11 patients without airway obstruction and 13 patients with emphysema. The regression line shown is for the normal subjects and for the patients without airway obstruction.

\section{DISCUSSION}

\section{Use of continuous sampling}

Since we used stable rather than radioactive $\mathrm{CO}$, direct comparison of our continuous sampling 


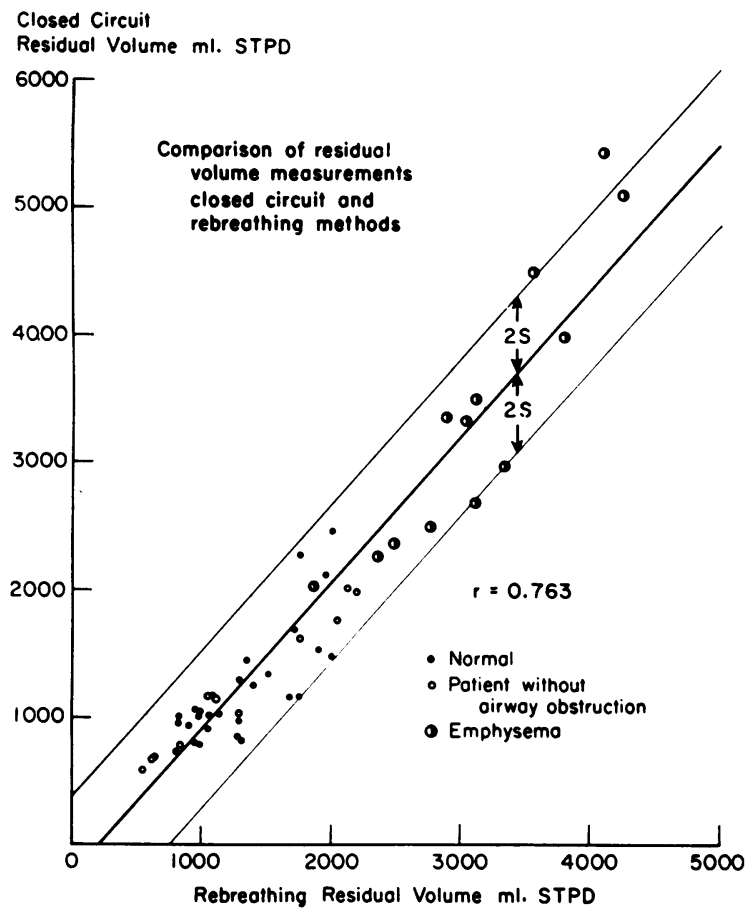

Fig. 9. Comparison of Residual Volume Measurements by Rebreathing and Closed Circuit Methods

The equation for the regression line is: residual volume (rebreathing) $=0.866$ residual volume (closed circuit) + $228 \pm 305$. " $\mathrm{S}$ " is the standard error of the estimate of this equation.

technique with Kruhøffer's (12) technique of three discrete samples from the same rebreathing bag was not possible. However, our finding (Table I) that analysis of final $\mathrm{CO}$ concentration in each of three bags of the same volume gives the same rate of $\mathrm{CO}$ absorption as continuous sampling indicates the time lag introduced by passing gas through the analyzer circuit does not introduce any significant error into the data reported here.

\section{Theory of carbon monoxide absorption during re- breathing}

We have used Krogh's equation (8) to calculate $\mathrm{DL}_{\mathrm{C} o}$ from the rate of fall of $\mathrm{CO}$ concentration during rebreathing. This is strictly valid

$$
\begin{aligned}
& \text { diffusion term } \\
& \mathrm{F}_{\mathrm{s}_{1}}=\mathrm{F}_{\mathrm{I}} \mathrm{e}^{-\frac{\mathrm{D}_{\mathrm{i}} \mathrm{Pb}_{\mathrm{t}}}{\mathrm{V}_{\mathrm{A}_{\mathrm{i}}}}} \times \sum_{1}^{\mathrm{N}} \phi_{\mathrm{i}} \frac{\mathrm{V}_{\mathrm{T}_{\mathrm{i}}}}{\mathrm{V}_{\mathrm{A}_{\mathrm{i}}}}
\end{aligned}
$$

only if the rate of rebreathing is infinitely fast. In this situation, the calculated $\mathrm{DL}_{\mathrm{CO}}$ is independent of variations in the ratio of diffusing capacity to alveolar volume $\left(D_{L} / V_{A}\right)$ or of diffusing capacity to alveolar ventilation $\left(\mathrm{D}_{\mathbf{L}} / \dot{\mathrm{V}}_{\mathrm{A}}\right)$ among the various alveoli, since lungs, dead space and bag constitute a single well mixed system. Calculated DL $\mathrm{LO}_{\mathrm{CO}}$ is also independent of increases or decreases in the volume of lungs, dead space or bag. The rate of rebreathing used in these studies (30 cycles per minute) is not "infinitely fast." However, it is sufficiently rapid to make the calculated DL $\mathrm{L}_{\mathrm{CO}}$ in normal subjects independent of increases in dead space (Figure 3 ). We, therefore, feel that the use of Krogh's equation (8) in such subjects is justified.

In subjects with emphysema, calculated $\mathrm{DL}_{\mathrm{CO}}$ is not independent of increases in dead space (Figure 4). Rebreathing must be considered as occurring breath by breath at a finite rate. The rate of fall of $\mathrm{CO}$ is obtained by dividing the concentration of one breath by that of the preceding breath. The first two of a series of equations for the concentration of $\mathrm{CO}$ in the rebreathing bag at the end of the successive breaths are given in Appendix II. These equations are of increasing complexity and it has not been possible to obtain an equation that can be solved for $D_{L}$ by dividing any such equation by that of the preceding breath.

Krogh's equation (8) can be applied to a rebreathing system that is ventilated breath by breath only if the following assumptions are made : 1 ) that ratio of diffusing capacity to alveolar volume $\left(D_{L} / V_{A}\right)$ is uniform for all alveoli. This same assumption is made in the single breath technique (17). 2) The dead space of apparatus and subject is negligibly small. 3) The time spent at end expiration is negligible in relation to the time spent in full inspiration.

The equation for the concentration of $\mathrm{CO}$ at the end of any breath then reduces to the product of a diffusion term and a mixing term. For the first two breaths these equations are:

mixing term

and

$$
F_{s_{2}}=F_{I}\left(e^{-\frac{D_{i} P b t}{V_{A_{i}}}}\right)^{2} \times \sum_{1}^{N} \phi_{i} \frac{V_{T_{i}}}{V_{A_{i}}}\left(\frac{\left(V_{A}-V_{T}\right)_{i}}{V_{A_{i}}}+\sum_{1}^{N} \phi_{i} \frac{V_{T_{i}}}{V_{A_{i}}}\right),
$$


TABLE IV

Calculated $D_{L}^{*}$ in lung model

\begin{tabular}{|c|c|c|c|c|c|c|c|c|c|c|c|}
\hline \multicolumn{4}{|c|}{ Region I } & \multicolumn{4}{|c|}{ Region II } & \multicolumn{4}{|c|}{$\begin{array}{c}\text { Entire lung } \\
D_{L}\end{array}$} \\
\hline $\mathrm{V}_{\mathrm{T}_{1}}$ & $V D_{1}$ & $\mathbf{V}_{\mathbf{A}_{1}}$ & $\mathrm{DL}_{L_{1}}$ & $\mathrm{VT}_{2}$ & $\mathrm{VD}_{2}$ & $\mathrm{~V}_{\mathbf{A}_{2}}$ & $\mathrm{DL}_{2}$ & R B & SB & $\overline{\text { SS }}$ & $I+I I$ \\
\hline $\begin{array}{r}570 \\
1,400 \\
1,400 \\
1,400\end{array}$ & $\begin{array}{r}46 \\
114 \\
114 \\
114\end{array}$ & $\begin{array}{l}2,000 \\
2,000 \\
2,000 \\
2,000\end{array}$ & $\begin{array}{r}8 \\
8 \\
3 \\
17\end{array}$ & $\begin{array}{r}1,280 \\
450 \\
450 \\
450\end{array}$ & $\begin{array}{r}104 \\
36 \\
36 \\
36\end{array}$ & $\begin{array}{l}4,500 \\
4,500 \\
4,500 \\
4,500\end{array}$ & $\begin{array}{r}17 \\
17 \\
22 \\
8\end{array}$ & $\begin{array}{l}24.9 \\
25.3 \\
22.4 \\
22.1\end{array}$ & $\begin{array}{l}25.6 \\
26.4 \\
10.7 \\
55.1\end{array}$ & $\begin{array}{r}24.8 \\
14.7 \\
7.1 \\
24.3\end{array}$ & $\begin{array}{l}25 \\
25 \\
25 \\
25\end{array}$ \\
\hline
\end{tabular}

* Abbreviations are as follows: $D_{L}$, diffusing capacity of lung or region; $V_{T}$, tidal volume of region; $V_{A}$, volume of region at full inspiration; $V_{D}$, dead space of region. Other abbreviations are as used in previous tables. $V_{T}, V_{A}$ and $V_{D}$ are milliliters STPD; $\mathrm{D}_{\mathrm{L}}$ is milliliters per millimeter $\mathrm{Hg} \times \mathrm{min}$.

where $\mathrm{F}_{\mathrm{I}}=$ concentration of $\mathrm{CO}$ in inspired gas, $\mathrm{F}_{\mathbf{s}_{1}}=$ concentration of $\mathrm{CO}$ in bag at end of Breath $1, \mathrm{~F}_{\mathrm{s}_{2}}=$ concentration of $\mathrm{CO}$ in bag at end of Breath 2, $D_{i}=$ diffusing capacity of ith alveolus, $V_{A_{i}}=$ volume of ith alveolus at full inspiration, $\mathrm{V}_{\mathbf{T}_{\mathbf{i}}}=$ tidal volume of ith alveolus and $\phi_{\mathrm{i}}=$ fraction of total $\mathrm{V}_{\mathrm{T}}$ contributed by ith alveolus. If complete mixing occurs on the first (or any subsequent) breath the mixing terms become equal. Consequently, the rate of fall of $\mathrm{CO}$ concentration obtained by dividing the equation for Breath 1 by that of Breath 2 is:

$$
F_{s_{2}}=F_{s_{1}} e^{-\frac{D_{i} P b t}{V_{A_{i}}}}
$$

The second and third assumptions made above, however, are certainly incorrect. Further, we have continuously analyzed the helium concentration of the rebreathing circuit and found that slow mixing continues throughout a 45 second period in emphysematous patients (18).

Thus the use of Krogh's equation (8) to calculate $\mathrm{DL}_{\mathrm{CO}}$ in a rebreathing system which is ventilated breath by breath at a finite rate may lead to errors in the value obtained. To evaluate the magnitude of these errors we have approached the problem empirically, using a mathematical model of the lung consisting of two regions (Figure 2). $\quad D_{L} / V_{A}$ and $D_{L} / \dot{V}_{A}$ are uniform within the region and may or may not be uniform between the regions (Table IV). With some labor, the concentration of an insoluble gas (helium) and a diffusible gas ( $\mathrm{CO}$ ) may be calculated at the end of each of the 23 breaths during a 45 second rebreathing period at 30 cycles per minute by expanding the equations in Appendix II. When the concentrations of $\mathrm{CO}$ are plotted on semilogarithmic paper, a final phase in which the disappearance of $\mathrm{CO}$ is apparently exponential is invariably obtained. A similar exponential phase was also obtained in a few calculations on a model lung consisting of four regions. When ventilation of the regions is uneven (Figure 2) slow mixing of helium continues during the apparently exponential disappearance of $\mathrm{CO}$. The $\mathrm{D}_{\mathrm{L}}$ calculated from this final phase of the CO curve approaches the true $D_{L}$ of the model most closely when both $\mathrm{D}_{\mathbf{L}} / \mathrm{V}_{\mathrm{A}}$ and $\mathrm{D}_{\mathbf{L}} / \dot{\mathrm{V}}_{\mathbf{A}}$ are uniform (Example 1, Table IV), but the variations from the true $D_{L}$ are relatively small when $\mathrm{D}_{\mathrm{L}} / \mathrm{D}_{\mathrm{A}}$ and $\mathrm{D}_{\mathrm{L}} / \dot{\mathrm{V}}_{\mathrm{A}}$ are not uniform as compared with the variations produced by nonuniform $D_{L} / V_{A}$ in the single breath $D_{L}$ and by non-uniform $D_{L} / V_{A}$ in the steady state $D_{L} \cdot{ }^{9}$ From the data shown in Table IV and other similar calculations we conclude that the value of DLCo calculated by a rebreathing method when the lungs are ventilated breath by breath as in emphysema, although approximate rather than exact, is not grossly in error.

Any practical consequence of this theoretical advantage, then, must rest on the demonstration that either $D_{L} / V_{A}$ or $D_{L} / \dot{V}_{A}$ is not uniform in the lungs of the subject under study. In normal subjects ventilation is uneven to some degree (19), but Marshall (20) has concluded from fractional analysis of expired air that $D_{L} / \dot{V}_{A}$ is uniform. The evidence bearing on the uniformity of $D_{L} / V_{A}$ in normal subjects is conflicting. Forster, Fowler, Bates and Van Lingen (21) from data on breath-holding for different periods of

\footnotetext{
9 The theoretical values for the steady state and single breath techniques in these model lungs are calculated from the equations given by Forster, Fowler and Bates (17). The total alveolar volume during breath-holding is 6,500 $\mathrm{ml}$. and the duration of breath-holding is 10 seconds. The effective tidal volume during the steady state technique is one-third that during rebreathing and the rate is 10 cycles per minute.
} 
time thought that it was not, while Marshall (20), after repeating the same experiment, concluded that $\mathrm{D}_{\mathrm{L}} / \mathrm{V}_{\mathrm{A}}$ is uniform. In emphysematous patients Marshall (20) found that $\mathrm{CO}$ concentration varied during a single expiration and concluded that $D_{L} / \dot{V}_{A}$ is non-uniform. Surprisingly, he also found that the ratio of an insoluble gas (helium) to $\mathrm{CO}$ during an expiration was uniform, indicating the same ratio of $D_{L} / V_{A}$ throughout the lung. Ogilvie, Forster, Blakemore and Morton (9) also found that the ratio of He to CO was the same in an "early" as in a "late" expiratory sample in patients with emphysema.

If $D_{L} / V_{A}$ is uniform in the lungs of normal subjects, there should be a high correlation between the rebreathing and single breath methods in these subjects. Such a correlation is found in our data (Figure 7). Further, the points for patients with emphysema scatter about the same regression line, supporting Marshall's (20) conclusion that $D_{L} / V_{A}$ is uniform in these patients. From the available evidence, therefore, the theoretical advantage that the rebreathing DL $\mathrm{LO}_{\mathrm{CO}}$ is independent of non-uniform $D_{L} / V_{A}$ (infinite rate) or relatively insensitive non-uniform $\mathrm{D}_{\mathrm{L}} / \mathrm{V}_{\mathrm{A}}$ (finite rate) does not make the rebreathing DL $\mathrm{LO}_{\mathrm{CO}}$ more valid than the single breath $\mathrm{DL}_{\mathrm{Co}}$.

If the same type of reasoning is applied to the relation between the steady state $D_{L_{C O}}$ and the rebreathing $\mathrm{DL}_{\mathrm{CO}}$, one would predict a high correlation between the two methods for normal subjects and a poor correlation for emphysematous patients. These predictions are not supported by our data (Figure 8). However, no conclusions seem warranted because 1 ) the data are relatively few, 2) the lung volumes during the measurements of rebreathing and steady state

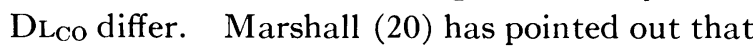
steady state $\mathrm{DL}_{\mathrm{CO}}$ increases with lung volume and we have found a similar relation of rebreathing $\mathrm{DL}_{\mathrm{CO}}$ to lung volume (Figure 6). 3) The steady state measurements were performed at rest and the potential errors of the steady state method are greatest at rest (10).

\section{Practical advantages of rebreathing}

The following practical advantages are unique to the rebreathing method:
1) The method incorporates a continuous internal check on $\mathrm{CO}$ analysis. The required measurements of $\mathrm{CO}$ are made within seconds of each other, while the rebreathing is going on. Further, the concentration of $\mathrm{CO}$ should fall exponentially during a valid study. Thus, any error due to malfunction of the analyzer or leak in the system is readily detected.

2) A measurement of residual volume is obtained simultaneously with a measurement of DLco. There is a satisfactory correlation between the residual volume so obtained and a measurement using a seven minute, closed circuit, helium technique (14) (Figure 9). A corollary advantage of the rebreathing method is that calculation of the total volume of the lung-bag system by helium dilution guards against errors which may occur in the single breath method through failure of the subject to expire to his residual volume at the start of the procedure.

3) A complete measurement of DLCO is very rapid. $\mathrm{CO}$ analysis is completed during rebreathing. The record of the $\mathrm{CO}$ analyzer may be measured at a minimum of three points while the rebreathing bag is analyzed for helium and carbon dioxide. All measurements and calculations can be completed in 10 minutes or less.

The following advantages of the rebreathing method are shared by either the steady state or the single breath methods:

1) No blood samples are required. 2) Rebreathing is readily carried out by patients and untrained subjects. 3) The method can be used in subjects with a low vital capacity. 4) Required analysis can be done by physical methods and without highly skilled personnel.

\section{Disadvantages of the rebreathing method}

The rebreathing method has the following disadvantages :

1) Rebreathing involves considerable exercise of the respiratory muscles. We have measured the oxygen consumption ${ }^{10}$ during rebreathing in six normal subjects by sampling continuously the oxygen concentration in the lung-bag system with a mass spectrometer. ${ }^{11}$ The difference in

\footnotetext{
${ }^{10}$ Strictly, we have measured the rate of oxygen uptake by the lungs. This may not be equal to oxygen uptake by the tissues during this brief, unsteady state.

11 Model 21-611 Consolidated Electrodynamics Corp., Pasadena, Calif.
} 
oxygen concentration between 10 and 30 seconds was multiplied by the total volume of the system and divided by the time interval to give the data shown in Table V. For comparison, the basal oxygen consumptions of these subjects, computed from body surface area using the standards of Aub and DuBois (22) are also shown. The oxygen consumption during rebreathing is about twice the basal level. The increase in DLCo corresponding to this increment in oxygen consumption apparently varies somewhat with the method. From the data collected by Forster (1), doubling the basal oxygen consumption might increase the steady state $\mathrm{DL}_{\mathrm{CO}}$ by as much as 20 per cent, but would change the single breath DLco by about 5 per cent.

The oxygen cost of hyperventilation, however, is greater in emphysematous patients than in normal subjects (23). The practical importance of the fact that rebreathing is moderately severe exercise in a patient with emphysema depends on the extent to which this patient can increase his DLCo on exertion. Bates, Knott and Christie (24) have reported that the steady state $\mathrm{DL}_{\mathrm{CO}}$ does not increase in emphysematous patients during treadmill exercise.

2) Alveolar $\mathrm{pO}_{2}$ falls during rebreathing. Roughton, Forster and Cander (4) have shown that the reaction rate of $\mathrm{CO}$ with hemoglobin is inversely proportional to $\mathrm{pO}_{2}$; hence, the lower the alveolar $\mathrm{pO}_{2}$ the greater $\mathrm{DL}_{\mathrm{co}}$. With the changes in alveolar $\mathrm{pO}_{2}$ during rebreathing, however, this effect cannot be large. In a subject with a capillary blood volume of $80 \mathrm{ml}$. and a membrane diffusing capacity of $50 \mathrm{ml}$. per $\mathrm{mm}$. $\mathrm{Hg} \times$ min., DLCo would be $27.2 \mathrm{ml}$. per $\mathrm{mm}$. $\mathrm{Hg}$ $\times$ min. at an alveolar $\mathrm{pO}_{2}$ of $105 \mathrm{~mm} . \mathrm{Hg}$ and $29.6 \mathrm{ml}$. per $\mathrm{mm}$. $\mathrm{Hg} \times$ min. at an alveolar $\mathrm{pO}_{2}$ of $65 \mathrm{~mm}$. $\mathrm{Hg}$.

3) Alveolar $\mathrm{pCO}_{2}$ rises during rebreathing. Rankin, McNeill and Forster (25) found that hypercapnia increased the single breath $\mathrm{DL}_{\mathrm{CO}}$. This effect varied with the duration of hypercapnia. When 10 per cent $\mathrm{CO}_{2}$ was added to the mixture inspired, DLCo increased 5 per cent after 10 seconds' breath-holding and 12 per cent after 50 seconds' breath-holding. When 7 per cent $\mathrm{CO}_{2}$ was breathed for 10 minutes before-

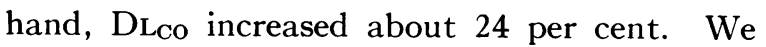
have no data on the effect of added $\mathrm{CO}_{2}$ on the
TABLE V

Oxygen consumption during rebreathing

\begin{tabular}{llc}
\hline Subject & $\begin{array}{c}\dot{\text { Vo2 }}^{*} \\
\text { Basal }\end{array}$ & $\begin{array}{c}\dot{\text { Vo2 }}_{\text {Oan }} \\
\text { Rebreathing }\end{array}$ \\
\hline W. G. & 208 & 280 \\
M. R. & 221 & 443 \\
J. C. & 208 & 317 \\
S. H. & 185 & 369 \\
J. McG. & 260 & 599 \\
J. N. & 273 & 425 \\
Average & 225.8 & 405.5 \\
\hline
\end{tabular}

$* \dot{\mathrm{V}}_{\mathrm{O}_{2}}$, oxygen consumption in milliliters STPD per minute. Basal $\mathrm{V}_{\mathrm{O}_{2}}$ calculated on basis of body size.

rebreathing DLCo, but the concentration of $\mathrm{CO}_{2}$ in the rebreathing bag after 45 seconds ( 6 to 7 per cent) is about that to be expected after holding a breath containing 10 per cent $\mathrm{CO}_{2}$ for 10 seconds.

\section{Results in normal subjects}

Our data, which show an average DLco of $27.3 \mathrm{ml}$. per $\mathrm{mm}$. $\mathrm{Hg} \times \mathrm{min}$. for 36 normal men and $19.7 \mathrm{ml}$. per $\mathrm{mm}$. $\mathrm{Hg} \times$ min. for 11 normal women, agree reasonably well with those of Kruh $\phi f f e r(12)$ who found that the average $D_{\text {Co }}$ of 10 normal men, rebreathing $\mathrm{C}^{14} \mathrm{O}$, was $27 \mathrm{ml}$. per $\mathrm{mm} . \mathrm{Hg} \times \mathrm{min}$. and the average DLco of five normal women was $22 \mathrm{ml}$. per $\mathrm{mm}$. $\mathrm{Hg} \times \min$. Like Kruhфffer we found that $\mathrm{DL}_{\mathrm{CO}}$ increases with height.

The rebreathing $\mathrm{DL}_{\mathrm{CO}}$ is well correlated with the single breath DLCo (Figure 7) and, like the single breath $\mathrm{DL}_{\mathrm{CO}}$, increases with body surface area, height and weight (9). Application of our regression equations and those of Ogilvie and associates (9) to subjects of the same physical parameters gives higher values for the single breath $\mathrm{DL}_{\mathrm{CO}}$, e.g., for a subject of $1.73 \mathrm{M} .^{2}$ body surface area the predicted single breath $\mathrm{DL}_{\mathrm{CO}}$ would be $25.8 \mathrm{ml}$. per $\mathrm{mm}$. $\mathrm{Hg} \times \mathrm{min}$. and the predicted rebreathing DLCo would be $23.3 \mathrm{ml}$. per $\mathrm{mm}$. $\mathrm{Hg} \times \mathrm{min}$. Similarly, in Figure 7 values for the single breath $\mathrm{DL}_{\mathrm{CO}}$ are, in general, higher than for the rebreathing DLCo in the same individual. These differences, however, do not reach the level of statistical significance.

The DLCo for normal females in our series is less than that for normal males. This is usually attributed to the smaller body size of women (1). Yet when our regression equations are applied to 
normal females, the predicted values are higher than those actually found. Thus, the average body surface area for our female subjects was $1.66 \mathrm{M}^{2}$, the average $\mathrm{DL}_{\mathrm{CO}}, 19.7 \mathrm{ml}$. per $\mathrm{mm}$. $\mathrm{Hg}$ $X$ min. and the predicted $\mathrm{DL}_{\mathrm{CO}}, 21.6 \mathrm{ml}$. per $\mathrm{mm} . \mathrm{Hg} \times$ min. Similarly, in the data of Ogilvie and co-workers (9) the average body surface area for women was $1.71 \mathrm{M} .^{2}$, the average $\mathrm{DL}_{\mathrm{CO}}$, $24.0 \mathrm{ml}$. per $\mathrm{mm}$. $\mathrm{Hg} \times \mathrm{min}$. and the predicted $\mathrm{DL}_{\mathrm{CO}}, 25.4 \mathrm{ml}$. per $\mathrm{mm}$. $\mathrm{Hg} \times \mathrm{min}$. These differences are suggestive rather than statistically significant.

The rebreathing DL $\mathrm{L}_{\mathrm{CO}}$ is irregularly higher than the steady state $\mathrm{DL}_{\mathrm{CO}}$ in the five normal subjects in our data (Figure 8).

\section{Results in patients}

Of our 19 patients with emphysema (Table III), in only five (N. F., E. N., J. C., G. V., W. F.) was the rebreathing DL $_{\mathrm{CO}}$ decreased a third or more below the predicted value based on body surface area (or weight). Thus, in 14 of these patients there was no marked impairment of diffusion. Kjerulf-Jensen and Kruhфffer (26), using a $\mathrm{C}^{14} \mathrm{O}$ rebreathing method, report similar findings. Only four of their 12 emphysematous patients had a $\mathrm{DL}_{\mathrm{CO}}$ a third or more below the predicted value. In 10 of our emphysematous patients, DL $L_{\text {Co }}$ was also measured by the single breath technique. Only three of these (S. P., G. V. and W. F.) had a value for DL $L_{C O}$ less than two-thirds of the predicted value. Marshall (20), also using the single breath technique, found that the DLCo was decreased by a third or more in only three of 11 emphysematous patients.

These findings must be contrasted with those of Ogilvie and associates (9), using the single breath technique; Bates, Knott and Christie (24), using the alveolar sample steady state technique and Donald, Renzetti, Riley and Cournand (27), using the steady state oxygen method. All of these investigators concluded that diffusion was usually impaired in emphysema.

When the same method gives conflicting results [cf. the results of Marshall (20) and of Ogilvie and associates (9)], the explanation presumably lies in the selection of patients. As far as the differences among the methods are concerned, we have set forth above our reasons for believing that the rebreathing DL $_{C O}$ gives reasonably valid results in emphysematous patients despite the fact that ventilation is grossly uneven in this disease. Marshall (20) has presented evidence that the alveolar sample steady state DLco gives erroneously low values in emphysema and Kjerulf-Jensen and Kruhфffer (26) have criticized the use of the Bohr integration for determining mean capillary $\mathrm{pO}_{2}$ in the steady state oxygen method (2).

$\mathrm{DL}_{\mathrm{CO}}$ in our four patients with sarcoid varied from markedly impaired (D. B. and M. B.) to normal (J.S.). Impairment of diffusion in sarcoid was first demonstrated by Austrian and co-workers (28). Williams (29) has emphasized the frequent occurrence of normal pulmonary function in sarcoid despite widespread pulmonary involvement by X-ray.

Other authors using different techniques have reported results similar to ours in interstitial fibrosis (28), radiation fibrosis (30), anemia (31), polycythemia (31) and the "Pickwickian" syndrome (32).

\section{SUMMARY}

1. This paper describes a rebreathing method for the measurement of pulmonary diffusing capacity for carbon monoxide $\left(\mathrm{DL}_{\mathrm{CO}}\right)$ using stable $\mathrm{CO}$ and continuous analysis.

2. The fall of CO concentration in the rebreathing bag was apparently exponential for at least 15 seconds in 571 of 578 studies. In 80.4 per cent of these studies, this exponential decrease began in the first 10 seconds of rebreathing.

3. In four normal subjects calculated $\mathrm{DL}_{\mathrm{Co}}$ was independent of increases in apparatus dead space. This would be true if the rate of rebreathing were infinitely fast.

4. In patients with emphysema calculated DL ${ }_{\text {Co }}$ decreases as apparatus dead space is increased. This would occur if the rebreathing system were ventilated breath by breath at a finite rate.

5. In four normal subjects the rebreathing DLCo decreased sharply when the total volume of the lung-bag system was decreased from near total lung capacity to approximately functional residual capacity.

6. In 47 normal subjects the rebreathing $\mathrm{DL}_{\mathrm{CO}}$ was significantly correlated with height, weight, body surface area and vital capacity.

7. There is a high correlation between rebreathing and single breath measurements of 
DLCo in normal subjects and patients without airway obstruction. There is a less striking correlation between these two methods in patients with emphysema.

8. The residual volume determined by the rebreathing method is significantly correlated with that measured by the closed circuit helium method in both normal subjects and patients.

9. An empiric argument is presented for the approximate validity of the rebreathing method in patients with uneven ventilation and slow mixing in whom the rate of rebreathing is finite.

10. The rebreathing method is rapid, simple and gives a simultaneous measurement of $\mathrm{DL}_{\mathrm{CO}}$ and residual volume.

11. The rebreathing DLCo was definitely decreased (two-thirds or less the predicted value) in only five of 19 patients with emphysema.

\section{APPENDIX I}

The diagnosis of emphysema in patients $\mathrm{H}$. K. through J. C. (Table III) was based on: 1) a low one second vital capacity and/or maximum breathing capacity, 2) an increased residual volume and 3) slight or no improvement in these tests after bronchodilators. All patients were dyspneic and their physical findings and $\mathrm{X}$-rays were compatible with chronic obstructive emphysema. Of these patients, complicating diseases were present in the following: S. P. (aneurysm of the abdominal aorta, carotid artery thrombosis), J. D. (peptic ulcer), N. F. (rheumatoid arthritis), E. N. (myocardial infarct), C. S. (peptic ulcer) and J. C. ("coin lesion" right lung). The chest X-ray of W. M. showed a large bulla in the left lower lung and the chest X-ray of W.F. showed a large bulla in the left upper lung field. Patients D. B. through J. S. had widespread, soft, patchy densities on X-ray of the chest. In each, either a scalene node (D. B., J. S.) or a lung biopsy (W. S., M. B.) was compatible with sarcoid histologically. D. B. and M. B. were dyspneic while W. S. and J. S. were working full time. W. Se. had relentlessly progressive dyspnea for two years. Chest $\mathrm{X}$-ray revealed diffuse fibrotic infiltration. E. J. received $\mathrm{Co}^{60}$ therapy after radical removal of carcinoma of the left breast. At the time of these studies she had a severe cough and a soft tissue density was present in the apical and infraclavicular portions of the left lung field. A. P. had widespread miliary calcific densities on chest X-ray. He was severely dyspneic. Histoplasmin and tuberculin skin tests were positive, but cultures for tuberculosis were negative. R. J. was diabetic and had a hemolytic anemia of unknown cause. His hemoglobin at the time of study was $8.0 \mathrm{Gm}$. per cent. W. Sh. was anemic because of bleeding from a small bowel tumor. Her hemoglobin was $6.9 \mathrm{Gm}$. per cent. The hemoglobin in S. S. was $18.6 \mathrm{Gm}$. per cent. G. G. had exudative lesions in both upper lung fields. Sputum smear was positive for tuberculosis. L. D. was somnolent, dyspneic, weak and grossly obese. H. B. had a markedly increased anteroposterior diameter of the chest with dorsal kyphosis. The lung fields showed increased radiolucency. F.H. was hypertensive $(190 / 90 \mathrm{~mm} . \mathrm{Hg})$ and had been in congestive heart failure twice before. He had a lesion of the left mid-lung field that proved to be carcinoma at thoracotomy. J. Sh. had the classic murmur of mitral stenosis. She had several episodes of acute pulmonary edema.

\section{APPENDIX II}

During the first breath of a rebreathing experiment the tidal volume $\left(V_{T}\right)$ of the subject flushes the dead space $\left(V_{D}\right)$ with the concentration of $\mathrm{CO}$ in the bag $\left(F_{I}\right)$ and brings $F_{I}\left(V_{T}-V_{D}\right)_{i} \mathrm{ml}$. of $\mathrm{CO}$ to the ith alveolus. This volume of $\mathrm{CO}$ is contained in the end inspiratory volume of the alveolus $\left(\mathrm{V}_{\mathbf{A}_{\mathbf{i}}}\right)$. Hence, the concentration of $\mathrm{CO}$ in the ith alveolus at the end of inspiration, which is assumed to be instantaneous, is $F_{I} \frac{\left(V_{T}-V_{D}\right)_{i}}{V_{A_{i}}}$. If full inspiration lasts $t$ minutes, this concentration falls because the ith alveolus has a certain diffusing capacity for $\mathrm{CO}\left(\mathrm{D}_{\mathrm{i}}\right)$. The rate of fall of $\mathrm{CO}$ concentration is the power of $\mathrm{e}$ (base of the natural logarithm) $e^{-\frac{\mathrm{D}_{\mathrm{i}} \mathrm{Pbt}}{\mathrm{V}_{\mathbf{A}_{\mathrm{i}}}}}$, where $\mathrm{Pb}$ is the pressure of dry gas in the alveoli. On expiration, which is also assumed to be instantaneous, the ith alveolus contributes a fraction $\left(\phi_{i}\right)$ of the total $\left(V_{T}-V_{D}\right)$. The concentration of $\mathrm{CO}$ in the rebreathing bag at end expiration $\left(\mathrm{F}_{\mathrm{s}_{1}}\right)$ is then a mixture of the contribution of the apparatus dead space $\left(V_{D_{a}}\right)$, the subject's dead space and what was expired from the alveoli. Thus,

$$
F_{s_{1}}=F_{I}\left(\frac{V_{D}+V_{D_{a}}}{V_{T}+V_{D_{\mathbf{a}}}}+\frac{V_{T}-V_{D}}{V_{T}+V_{D_{a}}} \sum_{1}^{N} \phi_{i} \frac{\left(V_{T}-V_{D}\right)_{i}}{V_{A_{i}}} e^{-\frac{P b t D_{i}}{V_{A_{i}}}}\right) .
$$

During full expiration, which also lasts $t$ minutes, the concentration of $\mathrm{CO}$ remaining in the ith alveolus falls by the power $\mathrm{e}^{-\frac{\mathrm{D}_{\mathrm{i}} \mathrm{Pb}_{\mathrm{t}}}{\left(\mathrm{V}_{\mathbf{A}}-\mathrm{V}_{\mathrm{T}}\right)_{i}}}$. On the second breath the concentration of $\mathrm{CO}$ in the dead space is $\mathrm{F}_{\mathrm{s}_{1}}$. The ith alveolus receives first a volume $\left(\mathrm{V}_{\mathrm{D}_{\mathrm{i}}}\right)$ of the mixed alveolar gas in the dead space at the end of expiration (the "alveolar" part of the equation for $\left.F_{s_{1}}\right)$ and then a volume $\left(V_{T}-V_{D}\right)_{i}$ of the gas in the bag. Both of these moieties are mixed with the gas remaining in the alveoli during expiration to give the concentration of $\mathrm{CO}$ at the end of the second inspiration. During a full inspiration of $t$ minutes, $\mathrm{CO}$ again diffuses out of the alveolus as explained above. The concentration of $\mathrm{CO}$ in the bag at the end of the second expiration $\left(\mathbf{F}_{\mathbf{s}_{\mathbf{2}}}\right)$ is :

$$
\begin{aligned}
F_{s_{2}}=F_{s_{1}} \frac{V_{D}+V_{D_{a}}}{V_{T}+V_{D_{a}}}+\frac{V_{T}-V_{D}}{V_{T}+V_{D_{a}}} \sum_{1}^{N} \phi_{i} & {\left[F_{I}\left(\frac{V_{D_{i}}}{V_{A_{i}}} \sum_{1}^{N} \phi_{i} \frac{\left(V_{T}-V_{D}\right)_{i}}{V_{A_{i}}} e^{-\frac{D_{i} P b t}{V_{A_{i}}}}\right)\right.} \\
& +F_{I}\left(\frac{\left(V_{A}-V_{T}\right)_{i}}{V_{A_{i}}} \frac{\left(V_{T}-V_{D}\right)_{i}}{V_{A_{i}}} e^{-\frac{D_{i} P b t}{V_{A_{i}}}} e^{\left.\left.-\frac{D_{i} P b t}{\left(V_{A}-V_{T}\right)_{i}}\right)+F_{s_{1}} \frac{\left(V_{T}-V_{D}\right)_{i}}{V_{A_{i}}}\right] e^{-\frac{D_{i} P b t}{V_{A_{i}}}} .}\right.
\end{aligned}
$$




\section{ACKNOWLEDGMENTS}

Dr. John D. McGinty assisted in several of these studies and in the statistical analysis. Dr. Robert E. Forster made several valuable suggestions regarding the theory of carbon monoxide absorption during rebreathing.

\section{REFERENCES}

1. Forster, R. E. Exchange of gases between alveolar air and pulmonary capillary blood. Pulmonary diffusing capacity. Physiol. Rev. 1957, 37, 391.

2. Riley, R. L., Cournand, A., and Donald, K. W. Analysis of factors affecting partial pressures of oxygen and carbon dioxide in gas and blood of lungs : Methods. J. appl. Physiol. 1952, 4, 102.

3. Bates, D. V. The measurement of the pulmonary diffusing capacity in the presence of lung disease. J. clin. Invest. 1958, 37, 591.

4. Roughton, F. J. W., Forster, R. E., and Cander, L. Rate at which carbon monoxide replaces oxygen from combination with hemoglobin in solution and in the red cell. J. appl. Physiol. 1957, 11, 269.

5. Roughton, F. J. W., and Forster, R. E. Relative importance of diffusion and chemical reaction rates in determining the rate of exchange of gases in the human lung. J. appl. Physiol. 1957, 11, 290.

6. Lewis, B. M., Lin, T., Noe, F. E., and Komisaruk, R. The measurement of pulmonary capillary blood volume and pulmonary membrane diffusing capacity in normal subjects; the effects of exercise and position. J. clin. Invest. 1958, 37, 1061.

7. McNeill, R. S., Rankin, J., and Forster, R. E. The diffusing capacity of the pulmonary membrane and the pulmonary capillary blood volume in cardiopulmonary disease. Clin. Sci. 1958, 17, 465.

8. Krogh, M. Diffusion of gases through lungs of man. J. Physiol. (Lond.) 1914, 49, 271.

9. Ogilvie, C. M., Forster, R. E., Blakemore, W. S., and Morton, J. W. A standardized breath holding technique for the clinical measurement of the diffusing capacity of the lung for carbon monoxide. J. clin. Invest. 1957, 36, 1.

10. Filley, G. F., MacIntosh, D. J., and Wright, G. W. Carbon monoxide uptake and pulmonary diffusing capacity in normal subjects at rest and during exercise. J. clin. Invest. 1954, 33, 530.

11. Bates, D. V., Boucout, N. G., and Dormer, A. E. The pulmonary diffusing capacity in normal subjects. J. Physiol. (Lond.) 1955, 129, 237.

12. Kruh $\varnothing f f e r, P$. Studies on the lung diffusion coefficient for carbon monoxide in normal human subjects by means of $\mathrm{C}^{14} \mathrm{O}$. Acta physiol. scand. 1954, 32, 106.

13. Sjostrand, T. A. A method for the determination of carboxy-hemoglobin concentrations by analysis of the alveolar air. Acta physiol. scand. 1948, 16, 201.

14. McMichael, J. A. A rapid method of determining lung capacity. Clin. Sci. 1939, 4, 167.

15. Van Slyke, D. D., and Sendroy, J., Jr. Line charts for graphic calculations by Henderson-Hasselbalch equation, and for calculating plasma $\mathrm{CO}_{2}$ from whole blood content. J. biol. Chem. 1928, 79, 781.

16. Peters, J. P., and Van Slyke, D. D. Quantitative Clinical Chemistry (Methods). Baltimore, Williams and Wilkins, 1943, vol. 2, p. 321.

17. Forster, R. E., Fowler, W. S., and Bates, D. V. Considerations on the uptake of carbon monoxide by the lungs. J. clin. Invest. 1954, 33, 1128.

18. Lewis, B. M., Hayford-Welsing, E. J., and McGinty, J. D. Helium mixing and carbon monoxide absorption during rebreathing. Fed. Proc. 1959, 18, 91.

19. Fowler, W. S. Intrapulmonary distribution of inspired gas. Physiol. Rev. 1952, 32, 1.

20. Marshall, R. A. A comparison of methods of measuring the diffusing capacity of the lungs for carbon monoxide. Investigation by fractional analysis of the alveolar air. J. clin. Invest. 1958, 37, 394.

21. Forster, R. E., Fowler, W. S., Bates, D. V., and Van Lingen, B. The absorption of carbon monoxide by the lungs during breathholding. J. clin. Invest. $1954,33,1135$.

22. Aub, J. C., and DuBois, E. F. The basal metabolism of old men. Arch. intern. Med. 1917, 19, 823.

23. Cournand, A., Richards, D. W., Bader, R. A., Bader, M. E., and Fishman, A. P. The oxygen cost of breathing. Trans. Ass. Amer. Phycns 1954, 67, 162.

24. Bates, D. V., Knott, J. M. S., and Christie, R. V. Respiratory function in emphysema in relation to prognosis. Quart. J. Med. 1956, N.S. 25, 137.

25. Rankin, J., McNeill, R. S., and Forster, R. E. Influence of hypercapnia on pulmonary diffusing capacity for CO in man. Physiologist 1957, 1, 68.

26. Kjerulf-Jensen, K., and Kruhøffer, P. The lung diffusion coefficient for carbon monoxide in patients with lung disorders, as determined by $\mathrm{C}^{14} \mathrm{O}$. Acta med. scand. 1954, 150, 395.

27. Donald, K. W., Renzetti, A., Riley, R. L., and Cournand, A. Analysis of factors affecting concentrations of oxygen and carbon dioxide in gas and blood of lungs: Results. J. appl. Physiol. 1952, 4, 497.

28. Austrian, R., McClement, J. H., Renzetti, A. D., Jr., Donald, K. W., Riley, R. L., and Cournand, A. Clinical and physiological features of some types of pulmonary diseases with impairment of alveolarcapillary diffusion. Amer. J. Med. 1951, 11, 667.

29. Williams, M. H., Jr. Pulmonary function in Boeck's sarcoid. J. clin. Invest. 1953, 32, 909.

30. Stone, D. J., Schwartz, M. J., and Green, R. A. Fatal pulmonary insufficiency due to radiation effect on the lung. Amer. J. Med. 1956, 21, 211.

31. Rankin, J., McNeill, R. S., and Forster, R. E. Diffusion characteristics of pulmonary membrane and capillary bed in various diseases of lungs and cardiovascular system. J. clin. Invest. 1957, 36, 922.

32. Burwell, C. S., Robin, E. D., Whaley, R. D., and Bickelmann, A. G. Extreme obesity assoriated with alveolar hypoventilation. A Pickwickian syndrome. Amer. J. Med. 1956, 21, 811. 